
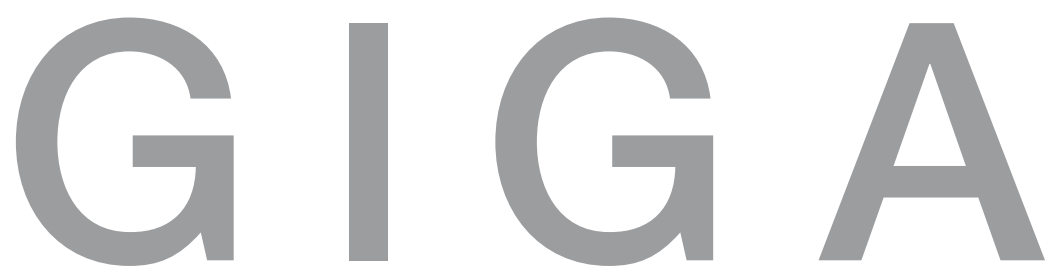

Working

German

Institute of Global and Area Studies Papers

Leibniz-Institut für Globale und Regionale Studien

GIGA Research Programme:

Legitimacy and Efficiency of Political Systems

Political Parties in Post-Suharto Indonesia: Between politik aliran and 'Philippinisation'

Andreas Ufen 


\section{GIGA Working Papers}

Edited by GIGA German Institute of Global and Area Studies / Leibniz-Institut für Globale und Regionale Studien.

The Working Paper Series serves to disseminate the research results of work in progress prior to publication to encourage the exchange of ideas and academic debate. An objective of the series is to get the findings out quickly, even if the presentations are less than fully polished. Inclusion of a paper in the Working Paper Series does not constitute publication and should not limit publication in any other venue. Copyright remains with the authors. When Working Papers are eventually accepted by or published in a journal or book, the correct citation reference and, if possible, the corresponding link will then be included in the Working Papers website at:

www.giga-hamburg.de/workingpapers.

GIGA research unit responsible for this issue: Research Programme 'Legitimacy and Efficiency of Political Systems'.

Editor of the GIGA Working Paper Series: Bert Hoffmann <hoffmann@giga-hamburg.de> Copyright for this issue: ( Andreas Ufen

Editorial assistant and production: Verena Kohler and Vera Rathje

All GIGA Working Papers are available online and free of charge at the website: www.giga-hamburg.de/workingpapers. Working Papers can also be ordered in print. For production and mailing a cover fee of $€ 5$ is charged. For orders or any requests please contact:

E-mail: workingpapers@giga-hamburg.de

Phone: ++49 (0)40 - 42825548

GIGA German Institute of Global and Area Studies /

Leibniz-Institut für Globale und Regionale Studien

Neuer Jungfernstieg 21

20354 Hamburg

Germany

E-mail: info@giga-hamburg.de

Website: www.giga-hamburg.de 


\title{
Political Parties in Post-Suharto Indonesia: Between politik aliran and 'Philippinisation'
}

\begin{abstract}
Surprisingly, the outcome of the 1999 and 2004 elections in Indonesia and the resultant constellation of political parties are reminiscent of the first Indonesian parliamentary democracy of the 1950s. The dynamics of party politics is still marked by aliran ('streams'), i.e. some of the biggest political parties still have a mass base and are embedded in specific milieus. But politik aliran has lost a lot of its significance and re-emerged in a quite different form after the fall of Suharto in 1998. Starting with this observation, it is argued that parties are still socially rooted, so a modified aliran approach still has its analytical value. However, one can also witness a weakening of aliran (dealiranisasi) and a concomitant 'Philippinisation', which is indicated by the rise of presidential or presidentialised parties, growing intra-party authoritarianism, the prevalence of 'money politics', the lack of meaningful political platforms, weak loyalties towards parties, cartels with shifting coalitions and the upsurge of new local elites.
\end{abstract}

Key words: political parties, post-Suharto Indonesia, Philippinisation, politik aliran

\section{Dr. Andreas Ufen,}

is Political Scientist and Senior Research Fellow at GIGA Institute of Asian Affairs in Hamburg, Germany.

Contact: ufen@giga-hamburg.de, website: http://staff.giga-hamburg.de/ufen 


\section{Zusammenfassung}

Politische Parteien in Indonesien nach dem Sturz Suhartos: Zwischen politik aliran und "Philippinisierung"

Die Ergebnisse der indonesischen Parlamentswahlen von 1999 und 2004 sowie die daraus resultierende Konstellation politischer Parteien erinnern überraschend stark an die erste parlamentarische Demokratie in den 1950er Jahren. Parteipolitische Auseinandersetzungen sind noch immer von aliran („Strömungen”) geprägt, d.h. einige der größten Parteien haben jeweils eine Massenbasis und sind in bestimmte soziale Milieus eingebettet. Aber das Phänomen der politik aliran hat viel von seiner ursprünglichen Bedeutung eingebüßt und ist nach dem Sturz Suhartos im Mai 1998 in einer deutlich veränderten Form wieder aufgetaucht. Ausgehend von dieser Beobachtung wird in diesem Working Paper argumentiert, dass Parteien immer noch sozial verwurzelt sind, so dass ein modifizierter aliranAnsatz weiterhin analytisch wertvoll ist. Allerdings lässt sich auch eine Schwächung der aliran (dealiranisasi) und damit verbunden eine „Philippinisierung” ausmachen. Letztere ist gekennzeichnet durch den Aufstieg präsidentieller oder präsidentialisierter Parteien, einen zunehmenden innerparteilichen Autoritarismus, das Vorherrschen von „money politics", das Fehlen aussagekräftiger politischer Programme, schwache Bindungen an die Parteien, Kartelle mit schnell wechselnden Koalitionen und einem Erstarken neuer lokaler Eliten. 


\title{
Political Parties in Post-Suharto Indonesia: Between politik aliran and 'Philippinisation'
}

\author{
Andreas Ufen
}

\section{Article Outline}

1. Introduction

2. The Heyday of politik aliran in the 1950s and the Erosion under Suharto

3. Parties and Elections since 1998: The Reconfiguration after Suharto

4. 'Philippinisation': Indications of Party Change

5. Conclusion

\section{Introduction}

After the fall of Suharto in May 1998, more than 200 political parties emerged. Eventually, 48 of them were allowed to participate in the June 1999 elections, the first free elections since 1955. Voter turnout was very high, as was the enthusiasm of the population. Surprisingly, the new party system that has emerged as a result of the election is reminiscent of that of the 1950s when Indonesia experienced parliamentary democracy for the first time. The dynamics of party politics is still marked by aliran ('streams'), i.e. some of the biggest political parties still have a mass base and are embedded in specific milieus. But politik aliran has lost a lot of its significance and re-emerged in quite a different form after 1998. Moreover, parties soon turned out to be characterised by all kinds of deficiencies. Most of them are ridden with internal conflicts, their financing is often shady, their platforms are vague and party elites tend to monopolise decision-making. Obviously, beyond old loyalties and ideologies, other forces are at work. 
In recent debates on political parties in Indonesia the salience of aliran is generally acknowledged (King 2003; Baswedan 2004), although often with certain reservations (Johnson Tan 2004; Sherlock 2004 and 2005). A few authors have focussed on deficiencies such as 'cartelisation' (Slater 2005) and formal institutional flaws (Sherlock 2005) or they have tried to assess the lacking or uneven institutionalisation of political parties (Johnson Tan 2006; Tomsa 2006b). Some Scholars question the validity of the aliran approach from a class perspective (Robison/Hadiz 2004; Hadiz 2004a and 2004b), others cite new evidence from regression analysis and raise serious doubts (Mujani/Liddle 2006). In connection with a range of recent studies on local politics (Hadiz 2004a; Choi 2004; Vel 2005; Mietzner 2007) the emergent picture is very complex. A more comprehensive approach to understand party politics in Indonesia today does still not exist.

This article analyses political parties from two different perspectives. It is argued that parties are still socially rooted, therefore a modified aliran approach still has its analytical value. At the same time, one can witness a weakening of aliran (dealiranisasi) and a concomitant 'Philippinisation', which denotes the convergence of some key traits of Philippine and Indonesian parties and party systems. In that way, the peculiar characteristics of party politics and the conflicting forces at play will be systematically pointed out.

Part 2 of this article helps to understand the concept of 'aliran' as interpreted in the 1950s since the term is now often used confusingly. It lays the base for a comparison of parties in the 1950s with those today, and it depicts in brief political party evolution until the fall of Suharto.

Describing Indonesia's political parties against the backdrop of aliran helps to elucidate the current, contradictory developments that are analysed in part 3 and 4 . The whole process is conceptualised as 'Philippinisation', which is indicated by the rise of presidential or presidentialised parties, the increasing intra-party authoritarianism, the prevalence of 'money politics', the lack of meaningful political platforms, weak loyalties to parties, cartels with shifting coalitions and the upsurge of new local elites.

\section{The Heyday of politik aliran in the 1950s and the Erosion under Suharto}

When the first political parties were established in Indonesia in the 1920s they were not able to fulfil their usual functions yet. Elections and real parliaments did not exist under colonial rule. As early mass-mobilisers, however, they consolidated social milieus and strengthened what later came to be known as aliran. In the 1950s and 1960s, the deep ideological roots of political parties were conceptualised by Indonesianists with this aliran (literally 'streams') 
approach. Clifford Geertz (1960) first outlined this model in his main work 'The Religion of Java'. His famous differentiation between abangan (syncretists stressing animistic beliefs), santri (followers of a purer Islam) and priyayi (those mostly influenced by a Hinduist aristocratic culture) had a lasting impact on further studies on Java. ${ }^{1}$ For the purpose of analyzing political parties in the 1950s, it is, however, much more practical to refer to a slightly different interpretation made by Geertz himself in 'Peddlers and Princes', where he conceptualised $\mathrm{PNI}^{2}$, Masyumi, NU and PKI as the organisational foci of aliran:

'As well as its political organization proper, each party has connected with it, formally or informally, women's clubs, youth and students groups, labour unions, peasant organizations, charitable associations, private schools, religious or philosophical societies, veterans' associations, savings clubs, and so forth, which serve to bind it to the local social system. For that reason, each party with its aggregation of specialized associations provides a general framework within which a wide range of social activities can be organized, as well as an over-all ideological rationale to give those activities point and direction' (Geertz 1963: 14). According to Geertz, this aliran complex is as much a social movement as a political party. Aliran were based on old forms of social integration with their concomitant world views, but political parties and associated organisations would not form a relatively stable pattern of inter-aliran relations until the 1950s. The four most important parties, which obtained fourfifths of the votes altogether in 1955 (see table 1), grew out of and at the same time reshaped and politicised these streams (Feith 1957: 31ff; Feith 1962: 125ff). The nationalist PNI represented those who were still set apart by an aristocratic Javanese culture and earned their living mainly as state employees and civil servants or were clients of them. ${ }^{3}$ The PKI was probably the best-organised party with loyal followers among abangan workers in urban and rural areas. ${ }^{4}$ The orthodox santri comprised modernists and traditionalists. The latter under

1 The abangan cultural variant (Geertz 1960: 6), typical of 'the more traditionalized peasants and their proletarianized comrades in the town' (Geertz 1960: 11), consisted of specific ritual feasts, spirit beliefs, sorcery, magic, etc. and stressed the animistic elements of the 'over-all Javanese syncretism'. The santri sub-tradition was characterised by the belief in a more orthodox Islam and was to be found mainly among traders and some sections of the peasantry. The priyayi variant referred mostly to the Hinduist aspects and had a deep impact on the bureaucratic culture of Java.

2 The party names are explained below in tables 1,2 and 3.

3 Abangan and priyayi orientations soon aligned 'into a unit as opposed to the santri' (Geertz 1965: 128). Geertz (1965: 129ff) has differentiated five predominant cleavages ('distinctions'): firstly, between a Javanist (priyayi-abangan) and an Islamic 'religio-ideological class'; secondly, between insaf (politically responsive) and masa bodoa (politically unresponsive); thirdly, between 'elite' and 'mass'; fourthly, between 'urban' and 'rural'; and fifthly, between 'modern' and 'traditional'.

4 The PKI comprised to a large extent not secularised, ideologically well-educated cadres. It had to adjust its revolutionary rhetoric to the religious worldviews of most of their abangan followers from Javanese villages and to construct patron-client relations. In 1964, the PKI had - according to 
NU consisted mostly of ulama (religious scholars) and their followers; the former under Masyumi comprised urban intellectuals, traders and artisans on the Outer Islands.

The first free and fair elections in 1955, particularly the long campaigning period, strengthened identification with aliran and often entailed bitter conflicts even in remote villages, for instance between PNI secularists and pious followers of Masyumi. Because of the immense fragmentation and polarisation of the party system, coalitions were generally fragile and short-lived. ${ }^{5}$

\section{Table 1: Election Results for the National Parliament (1955)}

\begin{tabular}{|l|c|c|}
\hline Party & Percentage & Seats \\
\hline PNI & 22.3 & 57 \\
\hline Masyumi & 20.9 & 57 \\
\hline NU & 18.4 & 45 \\
\hline PKI & 16.4 & 39 \\
\hline PSII & 2.9 & 8 \\
\hline Parkindo & 2.6 & 8 \\
\hline Partai Katolik & 2.0 & 6 \\
\hline PSI & 2.0 & 5 \\
\hline Others & 12.5 & 32 \\
\hline Total & 100 & 257 \\
\hline
\end{tabular}

Notes: PNI (Partai Nasional Indonesia, Indonesian Nationalist Party)

Masyumi (Majelis Syuro Muslimin Indonesia, Consultative Council of Indonesian Muslims)

NU (Nahdatul Ulama, Renaissance of Islamic Scholars)

PKI (Partai Komunis Indonesia, Indonesian Communist Party)

PSII (Partai Sarekat Islam Indonesia, Islamic Association Party Indonesia)

Parkindo (Partai Kristen Indonesia, Indonesian Christian Party)

Partai Katolik (Catholic Party); PSI (Partai Sosialis Indonesia, Indonesian Socialist Party)

Source: Rüland 2001.

The parties did not have any strong criteria for membership and were not able to build on a steady flow of revenues (Feith 1962: 122ff). Their leadership mostly comprised politicians with sceptical views on modern liberal democracy at least. Parties in the 1950s were deeply rooted, but elitist. They offered principal channels of access to the bureaucracy. Their power was, thus, based upon the control of segments of the bureaucracy, the military and state companies, as well as their connections to private entrepreneurs. ${ }^{6}$

its own figures - around 2.5 million party members (1954: 165.000) and 16 million members in associated mass organisations (Mortimer 1969).

5 Usually, NU and PNI or Masyumi and PSI worked together in these coalitions, which always excluded the PKI.

6 For example, whole ministries were transformed into gigantic stocks of prebends for political parties. NU hold sway over the department of religious affairs with 27,000 (1958) and 102,000 (1967) 
Because of institutional deficiencies (the excessive centralism, for example, which gave rise to regionalist movements from 1956 onwards), the rising power of the military, widespread corruption, the polarisation between secularists and Islamists in the Constitutional Assembly ('Konstituante' $)^{7}$ and the fundamental opposition of the PKI to liberal democracy, parliamentarianism slowly lost its legitimacy. In July 1959, Sukarno reintroduced the Constitution of 1945, which gave him wide-ranging authorities as president. Political parties lost most of their clout during this Guided Democracy period (1959-65). The cabinet and the parliament were maintained as instruments of Sukarno and the military leadership. Guided Democracy collapsed in 1965/66.

The elites of the New Order regime (1965/66-98) under Suharto started to depoliticise society, to centralise the administration and to streamline the political system. Parties were emasculated and token elections introduced. Political control was complemented by the 'simplification' of the party system in 1973, i.e. the forced fusion into three parties (see table 2). Golkar8, the regime vehicle, was always able to maintain a two-thirds majority in the national parliament, while the PPP and the PDI fulfilled the function of restricted opposition parties.

Table 2: Results of Parliamentary Elections 1971-1997 (\%)*

\begin{tabular}{|l|c|c|c|c|c|c|}
\hline & $\mathbf{1 9 7 1}^{* *}$ & $\mathbf{1 9 7 7}$ & $\mathbf{1 9 8 2}$ & $\mathbf{1 9 8 7}$ & $\mathbf{1 9 9 2}$ & $\mathbf{1 9 9 7}$ \\
\hline Golkar & 62.8 & 62.1 & 64.2 & 73.2 & 68.1 & 74.5 \\
\hline PPP & 27.1 & 29.3 & 28.0 & 16.0 & 17.0 & 22.4 \\
\hline PDI & 10.1 & 8.6 & 7.9 & 10.9 & 14.9 & 3.1 \\
\hline
\end{tabular}

* Protest voters - the 'White Group' (Golput = Golongan putih) - put blank ballot papers into the box. The share of invalid votes, including the Golput ballots, was 8.3\% (1971), 10.4\% (1977), 8.6\% (1982) and 8.7\% (1987) respectively (Inside Indonesia, June 1992: 5).

** Results after adding those of parties later merged: PPP (merger of NU 18.7\%; Parmusi 5.4\%; PSII 2.4\%; Perti 0.7\%); PDI (merger of PNI 6.9\%; Parkindo 1.3\%; Partai Murba 0.1\%; IPKI 0.6\%; Partai Katolik 1.1\%)

Notes: Golkar (Golongan Karya, Functional Groups)

PPP (Partai Persatuan Pembangunan, United Development Party)

PDI (Partai Demokrasi Indonesia, Indonesian Democratic Party)

Source: Rüland 2001.

The regime elites were set to erase politik aliran. Yet total control of such a diverse society was never attainable and the New Order ideologies were too shallow to have any far-

employees respectively. Until 1965, the Ministry of the Interior and the Information Ministry were domains of the PNI, while the PKI controlled large parts of the Ministry of Agriculture.

7 After the elections of 1955, the Konstituante was given the task of elaborating a new constitution, but was eventually dissolved by Sukarno.

8 Golkar was conceived as an assemblage of functional groups, not as a real political party. 
reaching impact on the public. Therefore, a very moderate variant of secular nationalism embodied by the PDI and a toothless version of political Islam represented by the PPP was tolerated.

At the height of the Asian financial crisis, the New Order crumbled not because of political party opposition but in the wake of student demonstrations and as a result of intra-elite conflict and bargaining.

\section{Parties and Elections since 1998: The Reconfiguration after Suharto}

The pressure to reform the polity was enormous immediately after the power transfer from Suharto to Habibie in May 1998. The new government had no other choice than to legalise the setting-up of political parties. Crucial legislation on elections, the composition of parliaments, political parties, etc. was passed by the New Order parties and MPs from the military without the direct consent of the newly established parties. In many ways it was a transition 'from above'. The most prominent oppositionists - Abdurrahman Wahid (PKB), Amien Rais (PAN) and Megawati Sukarnoputri (PDI-P) - were still sidelined until the election campaign in 1999.

A total of 148 parties were officially registered. After a long screening process, 48 of these were eventually allowed to take part in the June 1999 elections. All kinds of parties were created for specific professional groups (Partai Mencerdaskan Bangsa for teaching personnel), ethnic groups (Partai Reformasi Tionghoa Indonesia), workers (Partai Buruh Nasional, Partai Solidaritas Pekerja Seluruh Indonesia), women (Partai Perempuan Indonesia), old people (Partai Lansia Indonesia) and religious minorities (Partai Buddhis Demokrat Indonesia, Partai Katolik Indonesia, Partai Kristen Nasional Indonesia, etc.). Moreover, some Western-style parties such as Partai Hijau (Green Party) and Partai Demokrasi Liberal Indonesia (Liberal Democratic Party of Indonesia) were created in addition to the formerly illegal PUDI (Partai Uni Demokrasi Indonesia, United Democratic Party of Indonesia) and PRD (Partai Rakyat Demokratik, People's Democratic Party) with social democratic programmes, at least to a certain extent) (Suryakusuma 1999; Kompas 2004a and 2004b). All these groupings failed. To be successful, parties needed the infrastructure and connections built up during the New Order period (Golkar, PPP and, to a certain degree, PDI-P), the indirect backing of religious organisations (PKB, PAN, PPP, PBB, etc.) and grass-roots networks created long before (PK).

In the run-up to the polls there was a lot of speculation whether the aliran patterns of the 1950s would re-emerge. In the end, it turned out that politik aliran still plays a role, but in a 
different form than in the 1950s, and that some other mechanisms did shape the behaviour of parties and voters, too.

The results of the 1999 elections (Ananta/Arifin/Suryadinata 2004; Kompas 2004a) indicated a victory for moderate Islam and secularism. Parties which stood for a firm stance on Islamic issues with a tendency to support a conservative Islamisation of the country such as the PPP, PBB and PK performed badly and received only $14 \%$ of the votes altogether. The PKB and PAN, which predominantly have orthodox Muslim followers, gained almost a fifth of the votes together, but their secular, Pancasilaist orientation precluded most debates in the parliament on the introduction of sharia laws or even an Islamic state from the very beginning. In the 2004 polls (Sebastian 2004; Aspinall 2005; Hadiwinata 2006; Ananta/Arifin/Suryadinata 2005), no more than 24 parties were allowed to participate because of additional legal restrictions. ${ }^{9}$ Although the elections were essentially characterised by continuities, some telling shifts occurred which signified an acceleration of dealiranisasi from 1999 to 2004.

Golkar won 21.6\% (1999: 22.5\%) and is now the strongest party in the parliament. The PDI-P suffered a shocking defeat and lost more than 15 percentage points due to disappointment with the Megawati presidency and the performance of PDI-P politicians in general. The other huge surprise besides the devastating loss of the PDI-P and the sudden rise of Partai Demokrat was the triumph of the Islamist PKS (formerly PK), which won $7.3 \%$ of the votes. The party was even able to come first in Jakarta, ahead of the PD. These results revealed widespread dissatisfaction with established parties, particularly in the capital. PKB, PPP and PAN each lost slightly. Their dismal performance was only overshadowed by the trouncing of the PDI-P.

Six of the ten largest parties in the current national parliament are Islamic and four are secular (see table 3). The most important cleavage structuring the party system as a whole is the one dividing the secular and the Islamic parties. The latter are divided into moderate Islamic and Islamist parties. ${ }^{10}$ The polarisation between status quo- and pro-democracy parties immediately after the fall of Suharto soon died down. Today, this cleavage ${ }^{11}$ is hardly reflected

9 Only parties with at least ten MPs in the DPR or with more than three per cent of the votes in more than half of the province and district parliaments were allowed to participate in the 2004 elections. Moreover, they had to have branches in at least two thirds of the provinces and in at least two thirds of the districts in these provinces.

10 Islamist parties are defined here as those supporting the introduction of sharia law and aiming at instituting an Islamic state. Although the PKS does not officially embrace this agenda, they are classified as Islamist because of their ideological and organisational background.

11 The aliran and the cleavage approach are closely related. Cleavages are the result of fundamental societal conflicts. They structure the discourse on main issues and are institutionalised by political actors, especially parties (see Lipset/Rokkan 1967 as the locus classicus on cleavages). The terms abangan and santri do not simply denote groupings with different levels of commitment to their religion; at the same time they imply a socio-economic dimension because typically abangan prac- 
Table 3: Election Results for 1999 and 2004 (DPR)*

\begin{tabular}{|c|c|c|c|c|}
\hline Party & $\begin{array}{c}\text { Votes } 1999 \\
\quad(\text { in \%) }\end{array}$ & Seats 1999 & $\begin{array}{c}\text { Votes } 2004 \\
\text { ( in \%) }\end{array}$ & Seats $2004^{* *}$ \\
\hline Golkar & 22.5 & 120 & 21.6 & 127 \\
\hline PDI-P & 33.8 & 153 & 18.5 & 109 \\
\hline PKB & 12.6 & 51 & 10.6 & 52 \\
\hline PPP & 10.7 & 58 & 8.2 & 58 \\
\hline PD & - & - & 7.5 & 56 \\
\hline PK (2004: PKS) & 1.4 & 7 & 7.3 & 45 \\
\hline PAN & 7.1 & 34 & 6.4 & 53 \\
\hline PBB & 1.9 & 13 & 2.6 & 11 \\
\hline PBR & - & - & 2.4 & 14 \\
\hline PDS & - & - & 2.1 & 13 \\
\hline Other parties & & 26 & & 12 \\
\hline $\mathrm{TNI}^{* * *}$ & & 38 & & - \\
\hline Total & & 500 & & 550 \\
\hline
\end{tabular}

* The members of the First Chamber, the House of Representatives (Dewan Perwakilan Rakyat, DPR), are elected with a proportional system in multi-member constituencies. The Second Chamber, the People's Congress (Majelis Permusyawaratan Rakyat, MPR), consists of the DPR members and 132 representatives of the provinces. The latter constitute the relatively weak DPD (Dewan Perwakilan Daerah, House of Regional Representatives), which was established in 2004. They are elected with a majority system in multi-member constituencies and are not allowed to be members of political parties. Moreover, there have been direct presidential elections since 2004 and direct elections of mayors, district chiefs and governors since 2005.

** The allocation of seats was adjusted in accordance with a ruling of the Constitutional Court.

*** The military (TNI, Tentara Nasional Indonesia) automatically received 38 seats from 1999-2004.

Notes: Partai Golongan Karya (Golkar), Functional Groups Party

Partai Demokrasi Indonesia - Perjuangan (PDI-P), Indonesian Democratic Party - Struggle

Partai Kebangkitan Bangsa (PKB), National Awakening Party

Partai Persatuan Pembangunan (PPP), United Development Party

Partai Demokrat (PD), Democrat Party

Partai Keadilan (PK), Justice Party (2004: Partai Keadilan Sejahtera, PKS, Justice and Prosperity Party)

Partai Amanat Nasional (PAN), National Mandate Party

Partai Bulan Bintang (PBB), Crescent and Star Party

Partai Persatuan Pembangunan Reformasi (PPP Reformasi), United Development Party Reform (2004:

Partai Bintang Reformasi, PBR, Star Party of Reform)

Partai Damai Sejahtera (PDS), Prosperity and Peace Party

Source: Ananta/Arifin/Suryadinata 2005.

tices, for example, were tightly bound to specific milieus with their respective social bases. In terms of cleavages, the Geertzian framework encompasses a religious and a socio-economic divide at the same time. This highly complex model still tends to confuse actual debates on party politics in Indonesia. 
in the parliament at all. Golkar and PDI-P, for instance, are barely different when it comes to their stance on policy issues, their involvement in corruption scandals and the way the party apparatus is managed.

The secular parties are Golkar, PDI-P, PDS (essentially Christian) and PD. ${ }^{12}$ The PDI-P, which has a large following among Christians and secularists, is still identified with Sukarno, the immensely popular and charismatic first president of Indonesia. Megawati, his daughter and the party chairwoman, still embodies this Sukarnoist tradition.

The six Islamic parties are PKB (moderate traditionalist Islam), PPP (Islamist with modernists and traditionalists), PKS (modernist Islamist), PAN (moderate modernist), PBB (modernist Islamist, self-declared successor to Masyumi) and PBR (split from PPP). PKB and PAN define themselves as secular, but in reality they are moderate Islamic parties. PKB is directly connected to the traditionalist Islamic Nahdatul Ulama (NU), which officially has around 40 million members. PAN, in many ways the antagonist of PKB, has strong links to the urban, modernist Islamic mass organisation Muhammadiyah, which claims a membership of some 35 million.

Two parties of a new type also exist: the Partai Demokrat (Democrat Party) of President Susilo Bambang Yudhoyono, founded in 2001, and the Justice and Prosperity Party, PKS. Neither of them had any predecessors in the 1950s or the New Order. PKS is an efficiently organised, Islamist cadre party. Breaches of party discipline concerning moral behaviour or corruption are severely punished. The cadres are mostly young, well-educated men, and the party combines Western management techniques and Islamist indoctrination in a unique way. In contrast to them, Partai Demokrat is almost completely dependent on Susilo Bambang Yudhoyono. He used PD as a vehicle in the first direct presidential elections in 2004. Two of the four big parties of the 1950s (PNI, Masyumi, NU and PKI) have direct successors today. There is a clear continuation between PNI and PDI-P as well as between NU and PKB. Mayumi is now split into a few modernist parties, and the PKI simply does no longer exist. Golkar has taken up voters from different sources.

Although a number of differences between now and the 1950s exist, politik aliran is still salient. The party system is structured by some of the same underlying conflicts, i.e. between political Islam and secularism and between traditionalist and modernist Islam. But it would be misleading to simply transfer the Geertzian framework into contemporary party politics and to ignore fundamental social and cultural change. The dividing line between traditional-

12 One has to bear in mind that many Golkar voters, members and officials are orthodox Muslims. The former chairman of Golkar, Akbar Tanjung, was part of an influential alumni network of HMI (Himpunan Muslim Indonesia, Association of Muslim Students). The new chairman, Yusuf Kalla, has ties to NU. Because of this Baswedan (2004: 674) speaks of an 'Islam-friendly' party. Even many PDI-P voters, members and MPs are orthodox Muslims. 
ist and modernist Islam has become somewhat blurred, and even the differentiation between abangan and santri is questionable because of the expansion of orthodox Islam all over the archipelago (a process called santrinisasi). Whereas in the 1950s the proportion of abangan was supposedly around half or even two thirds of the total Muslim population, today the percentage has dropped significantly (Liddle 2003). The old priyayi culture is on the decline, and the radical political left was crushed in 1965/66. Primordial loyalties are weaker now than in the 1950s due to socio-economic progress, the improvement of educational facilities, urbanisation and the impact of the mass media.

Whereas in the 1950s ethnic or religious affiliation largely determined partisan loyalties and voting behaviour, the relationship nowadays is much more complex. In this context, Liddle and Mujani (2006) have demonstrated that prognosticating an individual's partisan choice in relation to his piousness (as defined by engaging in specific religious practices) is difficult today. Nevertheless, using bivariate and multiple regression techniques, King (2003) showed that there was a broad continuity in the election results (1955 and 1999) at the district level. He correlated support for major parties and found striking similarities that suggest that fundamental loyalties to parties, essentially defined in terms of religion, have survived in spite of socio-economic shifts.

Nevertheless, the usage of the terms abangan and santri today is questionable. It makes more sense to differentiate between 'followers of political Islam' (all of whom are orthodox Muslims) and 'secularists' (Christians, syncretists, and orthodox Muslims not interested in politicising their religion). Regression analysis may then lead to stronger correlations than Liddle and Mujani's (2006). ${ }^{13}$ This modified politik aliran model is different from the two versions presented by Geertz (1960 and 1963) and takes socio-economic and religious developments since the 1950s into account.

The 1999 and 2004 election results resemble in many respects those of $1955 .{ }^{14}$ But aliran nowadays are different and - what is more important - parties are no longer social movements with their own tight network of organisations (Antlöv 2004a: 12). They are typically led by very powerful leaders who have successfully centralised decision-making. Some of them, like Megawati Sukarnoputri and Abdurrahman Wahid, enjoy almost cult status. ${ }^{15}$ In the 1950s, factional disputes within parties were often ignited by ideological issues, whereas today bickering is more about leadership styles and positions. Parties nowadays control

13 See also the weak correlations between religiosity and voting in Ananta/Arifin/Suryadinata (2004). Arguably, the spuriousness is in this case a result of the vague differentiation between 'Muslim' and 'non-Muslim'.

14 See Liddle 2003; King 2003; Baswedan 2004; Antlöv 2004b; Cederroth 2004; Turmudi 2004; Johnson Tan 2006; Sherlock 2004 and 2005.

15 Cf. on this and the following: Fealy (2001: 102ff). 
their own militias, and elites distance themselves more often from party politics, inter alia because of the programmatical shallowness. ${ }^{16}$ During the elections of 1955, the impact of money politics was much less striking than nowadays. Candidates for party posts and for the legislature probably did not have to pay for being nominated. Though party financing in the 1950s was in many cases tainted by corruption or questionable influences, ${ }^{17}$ politics was not as closely interconnected with business as it is today. Moreover, parties in the 1950s relied on extensive networks at the village level and sought active support by village elites. ${ }^{18}$ Today, these networks in different forms still exist, but the direct identification with party leaders via the mass media has increased considerably.

These observations are underlined by a number of surveys conducted in recent years. ${ }^{19}$ They indicate that these transformations have indeed taken place. They illustrate, for example, that as a consequence of eroding social milieus, party loyalties are decreasing. A report by the Asia Foundation (2003), for instance, revealed that, with reference to the parliament elections, there is an extremely high proportion of non-identifiers or 'swing voters' in the electorate (Asia Foundation 2003: 100). The International Foundation for Election Systems found out in a nationwide survey (IFES 2004a) that 40.2\% of those who voted for Golkar in the 2004 parliamentary elections opted for Susilo and not for the official candidate of their own party, Wiranto, in the first round of the presidential elections. $23.7 \%$ of the PDI-P voters chose Susilo by ballot, and $22.7 \%$ of PPP voters cast their ballot for Amien Rais and not the party's candidate, Hamzah Haz. 40\% of the PBB electors, supposedly Islamists, supported Susilo.

Another IFES survey (IFES 2004b) revealed that $84 \%$ of those who had voted for the PBB, PBR, PKB and PAN voted for Susilo Bambang Yudhoyono and Yusuf Kalla in the second round of the presidential elections and that $82 \%$ of Golkar voters in the 2004 national elections voted for Susilo and Yusuf Kalla in the second presidential ballot, although the central leadership officially supported Megawati and Hasyim Muzadi.

16 'Almost all civil servants, including the top heads and including judges and public prosecutors, were party members. Only army and police members were forbidden membership in parties. When a prominent person was not formally a member of a party, it was common for him to be labeled on the basis of his personal association and general outlook' (Feith 1962: 124)

17 The financing of the PNI with its contacts to the state bureaucracy was especially questionable (Feith 1957: 26-27; Rocamora 1975: 112ff). Feith assumes that the PKI got foreign donations, whereas Muslim parties used their links to landowners, rubber growers, batik manufacturers, etc. NU was said to be poor. For its leaders, 'social resources', i.e. social and political relations in and around the villages, were more important than financial resources (Feith 1957: 28).

18 'The parties which were unable to establish an extensive network of village-level organization, and hoped instead to contact the villager through mass media, were quite unsuccessful - even where they had considerable financial resources and the advantages of occupancy of government power' (Feith 1957, 26).

19 On surveys until 2002: Johnson Tan 2002. 
A survey conducted by the Indonesian Survey Institute (Lembaga Survei Indonesia, LSI, 2006) shows that identification with political parties decreased from the elections in 2004 to early 2006 . Only $25 \%$ of more than 1,200 Indonesians could identify with a particular party. Another finding was that $90 \%$ of the voters were unaware of their parties' stance on the rice import policy and 94\% did not know what their stance was on the oil price increase, the latter probably being the most important political decision in 2005.

Another indicator of the dealiranisasi process, understood as a shift and weakening of the Geertzian aliran, is the dynamics of local politics. The pilkada ${ }^{20}$, i.e. the first direct elections of regional heads (governors, district chiefs and mayors) which started in 2005, have demonstrated that the selection of candidates by political parties, the decisions of voters, and the partisan coalition building were in most cases not the result of long-term loyalties in specific social milieus but of pragmatic decisions. Many coalitions were formed just for the sake of winning. In Maluku, even the PKS and the PDS, i.e. Islamists and supposedly fervent defenders of Christianity respectively, formed a coalition (Rinakit 2005; Djadijono 2006).

In summary, the aliran approach still seems to be quite a useful analytical tool as indicated by election results in 1999 and 2004 in comparison with those of 1955. Yet, the dealiranisasi process, which includes the behaviour of politicians and voters alike, calls for a much more elaborate concept to adequately grasp the inner workings of party politics in contemporary Indonesia.

\section{4. 'Philippinisation': Indications of Party Change}

A comparison with Philippine parties shall be introduced here in order to better understand the current and possible future dynamics of Indonesian party politics. The two countries are very similar as regards their socio-economic level, the quality of democracy (according to Freedom House and Polity IV), their political history (democracy in the 1950s, then neopatrimonial authoritarianism and re-democratisation) and key features of the system of government (presidentialism).

Political parties in the Philippines are characterised by a lack of meaningful platforms, by the high frequency of party-switching, short-term coalition-building, factionalism, as well as numerous dissolutions and re-emergences (Rocamora 2000; Arlegue / Coronel 2003; Teehankee 2006). The parties are mostly inactive in between elections, membership figures are low, as are levels of organisation. As a result, the party landscape is labyrinthine. Scores of parties with similar but meaningless names compete in a highly complex electoral system

20 Short for pilihan kepala daerah, 'election of regional heads'. 
every three years. The majority of them are just a few years old. They are often established or activated by presidential candidates who determine the selection of congressional and local candidates together with some other national political leaders and decide on essential issues in an authoritarian way. In the parliament, these parties serve as interest groups of MPs seeking easy access to financial sources. Since the president does not control an efficient party machinery, he or she is dependent on local elites when it comes to voter mobilisation. Campaigning is focused on the candidates, not on the parties. Another reason for their weak institutionalisation is the enormous size of campaign expenses. Parties not well-equipped financially in between elections raise their funds from their own MPs, their candidates and sponsors. The political elite in the Philippines is cartelised: politicians share the spoils of office, they block new competitors and fend off popular demands for fundamental reform.

In Indonesia, there is a trend of convergence with these Philippine traits of party politics. The most obvious ones, described in detail below, are the following: the rise of presidential parties, the authoritarian traits of parties which tend to be factionalised, the predominance of purely materialistic objectives ('money politics'), the lack of detailed programmes, weak allegiances towards parties, the construction of cartels with fluid coalitions, and the rise of local elites.

\section{The Rise of Presidential Parties and the Presidentialisation of Parties}

Since the constitutional amendments, the introduction of direct presidential elections and the strengthening of the presidency by raising levels for impeachment, the executive has grown stronger in relation to the parliament. Political parties have lost the ability to elect the president in the People's Congress (MPR) as they did in 1999.

The direct election of the president has facilitated the emergence of formerly insignificant parties as vehicles for presidential candidates. The best example is the Partai Demokrat utilised by Susilo Bambang Yudhoyono. ${ }^{21}$ Such a presidential party would have been inconceivable under the old system of indirect elections. PD has no real platform and still lacks a strong organisational structure, especially below the national level. At the last congress in 2005, Kristiani Herawati, the wife of Susilo and deputy leader of the party, reportedly engi-

21 The five pairs of candidates for the posts of president and vice-president respectively were (the nominating party is in brackets): Susilo Bambang Yudhoyono (PD) and Yusuf Kalla; Wiranto (Golkar) and Solahuddin Wahid; Megawati Sukarnoputri (PDI-P) and Hasyim Muzadi, Hamzah Haz (PPP) and Agum Gumelar; Amien Rais (PAN) and Siswono Yudohusodo. In the second round, Susilo and Yusuf Kalla beat Megawati and Hasyim Muzadi and had a clear majority of more than $60 \%$. 
neered the election of her brother-in-law into the office of party chairman. The PD will possibly just manage to survive as long as Susilo stays in office. ${ }^{22}$

In addition, one can argue that some of the other parties - like PDI-P, Golkar under Yusuf Kalla, PAN under Amien Rais and PKB under Abdurrahman Wahid - are being presidentialised because they are preparing their respective leaders (or their handpicked candidates) for the next presidential election in 2009 and are organising the party machinery accordingly. ${ }^{23}$ The result is authoritarian personalism (see below). ${ }^{24}$

Presidentialised parties tend to sacrifice policy concerns, ' (...) and party organization will be marginalised in setting the party's agenda and establishing the party's ideology' (Samuels 2002: 471). The elective presidency, especially with a two-ticket system in two rounds, furthers the blurring of ideological divides. The respective pairs of candidates for the presidency and the vice-presidency represent different levels of religiosity and dissimilar geographical areas. Accordingly, in the two rounds of voting in 2004 all kinds of surprising party coalitions were formed.

Poguntke and Webb (2005) state that presidentialisation takes place even in non-presidential systems: first, because of the internationalisation of modern politics which is accompanied by an 'executive bias' of the political process; second, because of the declining stability of political alignments that has reduced traditional party loyalties; and third, because of the increased capacity of political leaders to bypass their party machines and to appeal directly to voters. These factors have an impact upon parties in new democracies too.

\section{Internal Processes: Authoritarian Personalism and Factionalism}

Authoritarian personalism is to some extent a heritage of the political culture of the New Order. ${ }^{25}$ Party organisation was as centralised as the whole polity and intra-party decisionmaking as opaque and undemocratic as the authoritarian system in general. The oppression in the 1990s gave rise to charismatic, supposedly pro-democratic political leaders such as Megawati, Abdurrahman Wahid and Amien Rais. After 1998 the personalism was further

22 Tempo, 24-30 May 2005: National Democrat Party Congress: SBY's Chairman of Choice.

23 Moreover, there is a tendency to nominate popular artists such as soap opera actors as legislative candidates. PDI-P recruited Desy Ratnasari, Marissa Haque, Deddy Sutomo and singer Franky Sahilatua for the 2004 elections. The PKB enlisted actors Rieke Dyah Pitaloka and Ayu Azhari, and Golkar nominated Nurul Arifin. This practice is in part reminiscent of Philippine politics with former movie stars like ex-president Estrada or presidential candidate Fernando Poe.

24 See for instance Mujani/Liddle (2006) on the huge influence of the variable 'leadership' on party choice.

25 The personalisation is further boosted by the institution of direct presidential elections (cf. Mujani/ Liddle 2006). 
reinforced by the mass media, the presidential system and party laws benefiting central executives in Jakarta.

In most parties today, crucial decisions such as the nomination of candidates (Haris 2005: 9ff) are made by some core executive members who are usually loyal to one charismatic leader. The decision-making process is almost fully orientated from the top down to the branches. ${ }^{26}$ Furthermore, the statutes of most parties do not clearly regulate how party congresses and elections have to be organised (Notosusanto 2005). Sometimes these regulations are altered even at the beginning of conventions, with notorious examples being the recent congresses of Golkar and the PDI-P. ${ }^{27}$

The big political parties have designed the election and party laws to their advantage. They have banned individual or non-party candidatures and made it difficult for smaller parties to contest with their candidates. Regional parties are not admitted, with Aceh being the only exception. Law 31/2002 states that the Central Leadership Board (DPP) of a party must be located in Jakarta. The whole system of proportional representation strengthens the hold of central party leaderships. The newly introduced partially open-list proportional representation system makes it very unlikely that any one candidate will be elected according to this mechanism. As stipulated by Law 23/2003, only political parties or coalitions of political parties that obtained a minimum of three per cent of the seats in parliament or five per cent of the votes in the 2004 parliamentary elections are allowed to nominate pairs of candidates. In 2009 the minimum will be 15 per cent of the seats and 20 per cent of the votes.

Almost all parties have their power centre in Jakarta and chastise recalcitrant members. Intra-party opposition is marginalised in the PDI-P and the PKB in particular, sometimes by disregarding official party statutes. Noted PDI-P members such as Sophan Sophiaan, Indira Damayanti Sugondo, Meilono Suwondo, Arifin Panigoro and Haryanto Taslam were all sidelined as party critics or resigned as an expression of their disappointment with Megawati's leadership. One means of penalisation is to recall ${ }^{28}$ parliamentarians, i.e. to terminate their mandate and replace them. ${ }^{29}$ The right to do so, a typical New Order brainchild, was

26 In August 2005, the notorious businessman Fuad Bawazier quit PAN because it 'had violated its own democratic principles' after its central board issued a decree on 22 July, which bans provincial chapter members from electing regional executives who go against Jakarta's policy (PAN split wider as co-founder tenders his resignation, Jakarta Post, 15.8.2005).

27 End of family feud caps rift-ridden PDI-P congress, Jakarta Post, 2.4.2005.

28 Article 12 of Law No. 31/2002 on political parties states that party members who are elected legislative members can be dismissed from the legislative body if they lose their membership in their respective political parties.

29 Some MPs request to put a district system into practice in order to bolster the position of single parliamentarians and to counterbalance regional and national party leaderships. At the same time, the notorious recalling mechanism would be harder to apply. 
reintroduced in 2002. Furthermore, Megawati still has the right to decide on vital matters without consulting the executive council (hak prerogatif). The last congress in Bali in 2005 was characterised by the sole candidacy of Megawati and limited time for debating her accountability speech. Party critics were systematically silenced ahead of and during the convention. ${ }^{30}$

In the PKB, the Advisory Board (Dewan Syuro) stands above the executive council (Dewan Tanfidz) in many respects. Even the candidates for the Dewan Tanfidz have to get the acknowledgement of the Dewan Syuro beforehand (Notosusanto 2005). Major disputes in the PKB were solved in a problematic way to say the least. A long-simmering internal conflict between 'PKB Kuningan' around Abdurrahman Wahid and Alwi Shihab and 'PKB Batu Tulis' led by Matori Abdul Jalil crippled the party for months. Matori was eventually sacked, Alwi Shihab was declared interim party chairman. In 2004, Alwi Shihab and Syaifullah Yusuf, then chairman and general secretary respectively, were on the side of Susilo Bambang Yudhoyono during the presidential election campaign and were later rewarded with ministerial posts. Afterwards, however, they were sacked and not invited to the party congress in Semarang in 2005. Abdurrahman Wahid was elected chief patron of the Dewan Syuro by acclamation and not in accordance with party regulations. His nephew, Muhaimin Iskandar, was elected new party chairman - again by acclamation and without contender. ${ }^{31}$

At the last congress of PAN in Semarang in April 2005, long-time chairman and spiritus rector of the party, Amien Rais, stepped down, officially to promote rejuvenation. But again, Amien will continue to serve as a 'party advisor', which means in actual fact he will decide on salient issues. He picked little-known businessman Sutrisno Bachir as new party chairman after having 'convinced' other candidates not to compete. Sutrisno is a long-time admirer of Amien and financier of PAN.

Some of the examples above indicate that factionalism is widespread and often a direct result of intra-party authoritarianism. In many cases even new parties are formed. The PBB was shaken by disputes between two of its founders, Chairman Yusril Ihza Mahendra and Hartono Mardjono, the latter later chairman of the Indonesian Islamic Party (PII). ${ }^{32}$ Around the same time, PAN faced a similar crisis. ${ }^{33}$ The PBR, formed by popular preacher Zainuddin

30 Megawati Terpilih Aklamasi, Guruh Ikut (Megawati elected by acclamation, Guruh follows), Kompas, 1.4.2005; interview with Sukowaluyo, PDI-P, 4.10.2005. See also Gerakan Pembaruan PDI Perjuangan 2005.

31 Tempo, April 19-25, 2005: Wahid's Way; Muktamar Dinilai Tak Demokratis, Rekonsiliasi PKB Makin Sulit (Congress seen as undemocratic, reconciliation in PKB more difficult), Kompas, 20.4.2005.

32 Hartono Mardjono Dipecat PBB (Hartono Mardjono sacked by PBB), Republika, 24.2.2001.

3316 Anggota DPP PAN Resmi Mengundurkan Diri (16 central executive members of PAN officially step down), Kompas, 22.1.2001. 
MZ, is a splinter of the PPP and has been shaken by internal clashes itself. The PPP is again in danger of being divided by competing cliques. In the PDI-P, Dimyati Hartono and Eros Jarot, two Megawati critics, established a new political party, as did the rebels of the 2005 PDI-P party congress. ${ }^{34}$

\section{The Political Economy of Parties: 'Money Politics'}

Most political observers are particularly interested in institutions like party or electoral laws and tend to assess the political future of Indonesia rather optimistically, especially when they are funded by foreign organisations that work on improving the quality of democracy in Indonesia. In contrast, those analyzing Indonesian politics from a neo-marxist political economy standpoint take issue with mainstream functionalist approaches:

'(...) most of these parties are not «natural〉 political entities, carrying out 〈aggregating and <articulating functions, but constitute tactical alliances that variously draw on the same pool of predatory interests. Notwithstanding certain ideological schisms within and between parties, their function has primarily been to act as a vehicle to contest access to the spoils of state power' (Robison/Hadiz 2004: 228).

To Robison and Hadiz (2004a: 258), politics in Indonesia nowadays is '(...) driven increasingly by the logic of money politics'. Indeed, parties need financial support from private entrepreneurs. Membership fees are mostly insignificant, as is public funding. Regulations on party financing exist, but violations are hardly ever punished (Hadiwinata 2006: 106). Entrepreneurs presumably dictate (or 'influence') the stance of parties on specific issues. In recent years, some businessmen have become party heads such as Yusuf Kalla (Golkar) and Sutrisno Bachir (PAN). ${ }^{35}$ Financiers like billionaire Aburizal Bakrie are even rewarded with ministerial positions.

Furthermore, there are countless indications that candidates are chosen simply with regard to their financial weight. This is in contrast to the 1950s. 'Money politics' in different forms was not unknown at that time, but the elections in 1955 were characterised by '(...) remarkably little emphasis on money (...)' (Anderson 1996: 29). ${ }^{36}$

34 Oil businessman Arifin Panigoro, former investment minister Laksamana Sukardi, Roy B.B. Janis, Didi Supriyanto, Muchtar Buchori, Sukowaluyo Mintohardjo, Potsdam Hutasoit and others. A few months ago they founded the Democratic Renewal Party PDP (Partai Demokrasi Pembaruan).

35 Penguasa dan Pengusaha Kuasai Golkar (Powerful and businessmen dominate Golkar), Kompas, 22.12.2004; PAN Dipimpin Pengusaha (PAN led by businessman), Kompas, 12.4.2005.

36 Anderson mentions photographs of cabinet ministers before 1949 'in shorts and sandals' and in contrast to the congressional opulence of the Philippines. The revolutionaries '(...) were not at all sharply distinguished from one another in social origins or economic resources (...)' (Anderson 1996: 28). Part of this ethos of simplicity still imbued politicians in the 1950s. 
It is no secret that before the 2005 introduction of direct elections at the provincial, district and municipal levels, when the respective parliaments had the sole power to determine who became governor, bupati or mayor respectively, most of these competitions were decided by the disbursement of huge amounts of money to the councillors (Rifai 2003). The institution of direct elections at these levels did not erase 'money politics' but transferred it. In the pilkada the pairs had to pay their respective parties for the candidacy and they had to shoulder the campaign costs. They spent an average of US $\$ 10$ million at the provincial level and US\$1.6 million at the municipality/regency level (Rinakit 2005). The latest example is the race for governorship in Jakarta. ${ }^{37}$ To get the nomination as official candidate, one has to spend around US\$20 million, plus the campaign costs. This huge amount of money is the minimum a governor will have to earn once in office just to compensate his initial investment. ${ }^{38}$

That investments necessitate rent-seeking activities is a widespread phenomenon in parliaments, too. In the DPR the situation is as gloomy as at lower levels. In its corruption barometer report for 2004, for instance, Transparency International Indonesia (TI Indonesia) ranked the House of Representatives and political parties first in the corruption index (categorised as 'very corrupt'), followed by the customs and excise office, the judiciary, the police and the tax office. ${ }^{39}$ TI Indonesia's secretary general Emmy Hafild listed various manifestations of corruption that included the bribery of House members who planned to scrutinise entrepreneurs on their dubious activities, the activities of MPs as brokers to help private companies get government contracts, and financial rewards from public officers in 'fit and proper tests' before parliament. Furthermore, political parties were used by corruptors from the previous regime as safe havens from corruption litigation. ${ }^{40}$

In early October 2006, the DPR working group on law enforcement and regional administration recommended that the government should rehabilitate the names of regional heads and council members implicated in corruption cases. Indonesia Corruption Watch (ICW) states that at least 55 corruption cases involving 350 public officials and lawmakers were filed with district courts from January 2005 to June 2006, and about 1,200 regional council members were named suspects, charged and convicted of corruption from 1999 until the end of $2004 .{ }^{41}$

37 Tempo, 5-11 Sept 2006: The Lure of the Governorship.

38 Out of 10 governors in Sumatra 7 are businessmen. If the candidates themselves are not wealthy, they have to be backed by investors who are usually members of so-called success teams (tim sukses) during campaigns (see for instance Vel 2006: 84).

39 House, parties 'most corrupt', Jakarta Post, 10.12.2004.

40 House, parties 'most corrupt', Jakarta Post, 10.12.2004.

41 Govt told to get tough on corrupt lawmakers, Jakarta Post, 7.10.2006; House calls for halt to graft trials of local leaders, Jakarta Post, 11.10.2006. 


\section{The Fading Connection between Parties and Voters: Weak Platforms and Diminishing Party Loyalty}

Most parties have vague platforms. Out of the 48 which were officially accepted in 1999, eight were Islamic by their own definition, five were based on the Pancasila ${ }^{42}$ and Islam, 31 solely on the Pancasila, two on the Pancasila and other teachings (social democratic or Marhaenist) and two exclusively on other teachings (PUDI on 'religious democracy' and the PRD on 'people's social democracy') as their ideology (Suryakusuma 1999: 592 and 596). Six parties had a bull on a red background as their symbol, denoting a Marhaenist, i.e. Sukarnoist platform, but they preferred to be seen as Pancasilaist. In 2004, out of the 24 parties contesting the parliamentary elections, 13 opted for Pancasila as their core ideology, five for Islam, two for Marhaenism and the other four small parties for a combination of Pancasila with the UUD 1945 (Constitution of 1945), for Pancasila with 'Justice and Democracy', and for Pancasila based on the family principle (kekeluargaan) and 'mutual help' (gotong royong) respectively (Djadijono 2006). Even a devoutly Christian party like the PDS does not refer to Christianity, but to the Pancasila.

Consequently, the main parties in Indonesia are essentially either Islamic or secular with reference to their ideology, i.e. based on the Pancasila. But even the Islamic parties in general do not oppose the principles expressed by the Pancasila formula, which is hazily phrased and hardly adequate as a platform for political parties. The Sukarnoist parties add 'Marhaenism' to their main agenda, which denotes - again in very general terms - a commitment to represent the 'little people' (as epitomised by Marhaen, supposedly a peasant Sukarno once met). Most parties are, thus, engaged in a fight for the middle ground. Essentially Islamic parties like PAN and PKB have chosen a neutral platform in terms of religion; even an Islamist party like PKS is not willing to play the Islamic card during elections, but rather focuses on issues such as the fight against corruption.

The fact that platforms are shallow is not surprising in the face of global developments. After the collapse of communism, during a profound crisis of social democracy and decreasing political polarisation in many Western countries, party programmes have been losing their clear contours. In Europe, the typical characteristics of catch-all parties are still salient: a drastic reduction of the party's ideological baggage, the further strengthening of top leadership groups, a downgrading of the role of the individual party member, the de-emphasis of the specific social-class or denominational clientele, and the objective to securing access to a

42 The five principles (Pancasila, the so-called state philosophy) are: belief in the one and only God; just and civilised humanity; the unity of Indonesia; democracy guided by the inner wisdom in the unanimity arising out of deliberations amongst representatives; and social justice for the whole of the people of Indonesia. The Pancasila still symbolise the acknowledgement of religious freedom. 
variety of interest groups (Kirchheimer 1966). In Indonesia, Golkar and PDI-P are the most obvious versions of catch-all parties.

Weak platforms indicate that the link between parties and voters is loosening and that the rootedness in milieus is decreasing. In a national survey, the Asia Foundation found out that linkages between voters and parties are mostly 'emotional' and not based on meaningful knowledge of the specific platforms of parties:

'The widespread lack of party preferences, other than those based on emotional identification, can largely be explained by the fact that most Indonesians are unaware of differences among the political parties. Two-thirds of the voters (66\%) say they do not know what differences exist among the parties or that there are none' (Asia Foundation 2003: 100).

After elections, voters in Indonesia are hardly interested in everyday party work and are generally ill-informed on policy issues. Campaigning lacks content. Voters largely do not elect parties along the lines of their platforms.

\section{The Collusive Relationship between Parties: Cartels and Shifting Coalitions}

In a widely quoted article, Katz and Mair (1995) outlined how western European catch-all parties have been transformed into parties constituting a cartel. Cartel parties are related to the state symbiotically, they are estranged from society and are dominated by public officeholders. Party activists have only marginal influence upon internal decision-making procedures and election campaigns are organised by professional experts. ${ }^{43}$ These parties together form a cartel in that they fend off new competitors and share the spoils of office. Slater (2004) sees a parallel phenomenon in Indonesia. The existence of cartels is among other things indicated by rainbow coalitions (koalisi pelangi), the lack of an organised opposition in most parliaments, the evasion of open voting and the lack of willingness to crack down on corruption. When - according to Slater (2004: 75ff) - the cartel was endangered by the elusive policies of President Abdurrahman Wahid, who started to sack ministers and finally even tried to ban Golkar, the colluding political elites reacted by impeaching and ousting him.

Cartels are in some measure a result of a fragmented party system with unclear majorities. ${ }^{44}$ Abdurrahman Wahid was forced to form a grand coalition in October 1999 because his party

43 The latter point is well illustrated by Mietzner (Opportunities, pitfalls of RI's new democracy, Jakarta Post, 16.10.2006) in his analysis of the rising influence of opinion polls in Indonesia on shaping the behaviour of political party elites.

44 Conceivably, the fragmentation of the party system in Indonesia is not the result but the cause of the proportional system. The choice of this system after independence and again in 1998/99 was due to the high number of relevant political actors. The introduction of a majority system seems to be more probable if there are just two major players (Nohlen 2004: 408 and 415ff). 
had received only $12.6 \%$ of the votes. ${ }^{45}$ After the overthrow of the Abdurrahman Wahid government in July 2001, Megawati herself depended on the support of a range of parties which then were rewarded with cabinet positions. Susilo Bambang Yudhoyono did not have the backing of a strong party since his PD received just 7.5\% of the ballot. ${ }^{46}$ Only when Yusuf Kalla became Golkar chairman in December 2004 and steered the party towards the Yudhoyono government did the president gain a sufficient majority in the DPR.

Difficulties of interparty coalition-building often arise in presidential systems, especially when combined with multipartism. Executive/legislative deadlock can sometimes be the result (Mainwaring 1993). In Indonesia, these tendencies brought the parliament to a virtual standstill in 2001 during the prolonged impeachment process against Abdurrahman Wahid, and this happened again in late 2004. But these phases of immobility gave way to new coalitions formed to rescue the underlying logic of cartelisation.

The sudden change of guard at the top of Golkar in late 2004 can be interpreted as a manoeuvre to secure the benefits of governing in Jakarta, i.e. ministerial posts. ${ }^{47}$ The move by party delegates to vote for the incumbent vice-president, Yusuf Kalla, and sideline Akbar Tanjung testifies to the strength of directly elected politicians and is reminiscent of the opportunism of MPs in the Philippines, who switch into the camp of the new president immediately after elections. ${ }^{48}$ Only now a supposedly strong president with a parliamentary majority has emerged. A stable pattern of 'government' versus 'opposition' has not developed yet, however. In many regional and provincial assemblies, too, opposition to the cartels is organised only by a handful of councillors. ${ }^{49}$

45 Coalitions are generally not based on well-defined contracts outlining government objectives and peculiar interests of political parties as members of this coalition. Co-operation among parties is fluid and strongly dependent on the outcome of power struggles in these parties.

46 He therefore tried to co-opt other parties. But ahead of the second round of the presidential elections, Golkar, under the leadership of Akbar Tanjung, decided to side with Megawati, although Yusuf Kalla was Susilo's running mate. After the victory of Susilo and Yusuf Kalla, a marked polarisation occurred between Susilo's 'People's Coalition', which comprised the PD, PAN, PPP, PKS as well as other small parties grouped in the 'Democratic Pioneer Star' (BPD) faction, and the 'Nationhood Coalition', which was made up of the PDI-P, Golkar, PDS and PBR with the support of the PKB. The main issues were the installation of the 11 parliamentarian sub-committee chairmen and the appointment of the chief of the armed forces. Some of the ministers in Susilo's cabinet were not acknowledged by their own parties. In October 2004, the PPP also left the 'Nationhood Coalition', inter alia because two PPP members - Suryadharma Ali and Soegiharto - were accepted as ministers by Susilo Bambang Yudhoyono.

47 On the whole episode, see Tomsa (2006a: 17ff).

48 But unlike Philippine politicians, MPs in Indonesia hardly ever switch parties, at least at the national level.

49 Interview with Anang Rosadi Adenansi, PKB, member of the provincial parliament of South Kalimantan, Banjarmasin, 1.9.2005. See also Slater (2004: 63). 
The clearest indication of a cartel-like organisation of political parties is the peculiar decision-making mechanism called 'musyawarah dan mufakat' ('deliberation and consensus'), which predominates in Indonesian parliaments. Consistent with the Rules of Procedure of the DPR (Peraturan Tata Tertib DPR-RI, 2001), most decisions in commission and plenary meetings of the legislatures are taken consensually and without voting. This causes delays and makes it extremely difficult for the public and even for political observers to trace back the initial stance of particular parties on particular political issues (Sherlock 2005). Even if parties express their views publicly from time to time, they often switch unexpectedly to contrary positions. In the national parliament, for example, the fuel subsidy cuts were initially resisted by PPP, PKS, PAN and PKB, but finally they all backed down. This tactic of first opposing and finally co-operating was repeated many times, as in the case of the planned probe into rice imports from Vietnam, with the PKS being the only exception, and with the purchase of 32 French-made armoured vehicles without public bidding. 'The Forum of Citizens Concerned about the Indonesian Legislature' (Formappi) stated, thus, that parliamentarians favoured lengthy debates, posturing to action, and speaking out against government policies, but generally supported the criticized bills after backroom deals. ${ }^{50}$

\section{The Upsurge of New Local Bosses}

The collapse of the New Order, where regional heads were appointed by the Minister of Domestic Affairs, and the administrative and political decentralisation since then have strengthened local elites. The devolution of political power to the district (kabupaten) level and the concomitantly increased budgets have made local politics more competitive and political positions more attractive. The centralised neo-patrimonialism of the New Order with Suharto as the highest patron has given way to a decentralised neo-patrimonialism with a range of interwoven national and regional patron-client networks.

Local politics, tightly controlled by the military regime under the New Order at least until the early 1990s, is increasingly marked by 'predatory networks' (Robison/Hadiz 2004) and may evolve into outright 'bossism' (Sidel 1999). Although the central leaderships of political parties can dictate most decisions on policy issues and are able to push through their candidates for the national parliament and for their respective central executives, a tug of war between Jakarta and the regions is usual at lower levels (Choi 2004).

Clientelist relationships that more often than not exist on a purely monetary basis predominate. Even before the introduction of the pilkada, political thuggery and 'money politics'

\footnotetext{
50 House faces criticism for bowing to government, Jakarta Post, 28.9.2006.
} 
were on the rise (Choi 2004). ${ }^{51}$ Since then, militia activities have subsided. ${ }^{52}$ Political violence during election campaigns since 2004 was not marked by widespread and systematically used violence as was the case in the Philippines. Nevertheless, local strongmen have emerged. In some regions an explosive mixture of decentralisation, the opening-up of new avenues to government spoils, and the re-accentuation of regional or cultural identities has evolved.

The pilkada have not only strengthened but also weakened local and regional party leaders in a way, for many of the candidates were chosen from civil servants or businessmen without any strong party links despite the fact that parties had the nomination right. Often, candidates were not party members initially or they belonged to party A but ran for party B. At this level, popular candidates look around for those parties offering them the best opportunities, and party institutionalisation at the local and regional level is much weaker than at the national level in Jakarta. Party offices, for example, are generally inactive in between elections. ${ }^{53}$

At the grass-roots level, political parties frequently did not have adequate, i.e. well-to-do, popular candidates. The pilkada, thus, were an arena for well-connected bureaucrats and wealthy businessmen who both profited from candidacies auctioned off by weakened parties (Mietzner 2005 and 2007). ${ }^{54}$ This constellation strengthened tendencies of dealiranisasi and of entrenching newly emerging local oligarchies.

51 'Islamic' militia groups have been at least as ubiquitous in Yogyakarta as the notoriously chaotic and brutal satgas (paramilitary wing) of the now powerful PDI-P. Such Islamic-oriented militias include the Gerakan Pemuda Ka'bah (Ka'bah Youth Movement), loosely linked to the United Development Party (PPP) (...) and the Islamic Defence Front (FPI), itself allegedly associated with a number of Islamic political groupings. (...) In North Sumatra, racketeering is largely the domain of old New Order 'youth' / crime organizations like the Pemuda Pancasila (Pancasila Youth) - originally set up to help the military confront the Indonesian Communist Party in the 1960s - and its powerful local rival, the Ikatan Pemuda Karya (IPK; Functional Youth Group). A number of members from such organizations currently occupy local parliamentary seats across the province. Two have won post-Soeharto elections for bupati and mayor in North Sumatra" (Hadiz 2004: 715). See also on these new local elites: Widodo 2003.

52 Many political parties have formed their own paramilitary forces. Examples are the 'Task Forces' (Satgas) of PDI-P, the Kabah Youth Movement (Gerakan Pemuda Kabah, GPK) of PPP, the National Guard (Gerakan Pemuda Kebangkitan Bangsa, Garda Bangsa) of PKB and the PAN Youth Force (Barisan Muda PAN). The Banser (Barisan Ansor Serbaguna) of PKB probably has around 100,000 members. They '( ...) have been behind many violent action campaigns, most notably when President Wahid was given a hard time by the media for his adulterous affairs and corruption" (Bertrand 2004: 339).

53 Personal communication with Michael Buehler, Jakarta, 7.10.2006.

54 According to Rinakit (2005), 87\% of regional elections in 2005 were won by the incumbents, local bureaucrats and military personnel. 
In sum, new local and regional political elites have emerged. To some extent they are checked by politicians in Jakarta and are often not identical with well-established local or regional party leaders. Therefore, the empowerment of new local bosses has not reached Philippine proportions yet. Local or regional elites do not have a decisive impact on national politics in the DPR or in the central executives of political parties. And the DPD (Dewan Perwakilan Daerah or House of Regional Representatives) is insignificant in comparison to the DPR. Moreover, its delegates are not allowed to be members of political parties.

\section{Conclusion}

The two comparisons with the political party system of Indonesia in the 1950s and with the current one in the Philippines help to elucidate two fundamental types of dynamics shaping the Indonesian party system since 1998: the enduring impact of politik aliran and the eroding effects of 'Philippinisation'.

The first national elections in 1955 resulted in a party system structured by aliran. During the Guided Democracy period (1959-1965) some major cleavages were deepened which brought about civil war. Throughout the New Order era (1965/66-1998), opposition was restrained and politik aliran subdued, but the root causes of social conflict were by no means eliminated. In spite of four decades of authoritarianism, which effectively restricted the organisational freedom of political parties, many of the old parties re-entered the political realm after 1998. The PKB, for example, whose predecessor was the NU party of the 1950s, is based on a large network of mostly rural, religious boarding schools (pesantren) and their charismatic principals, the kiai, and the PDI-P (1955: PNI) is a secular party thriving on the lasting charisma of former president Sukarno. The modernist Masyumi now has a few successors (PBB, partly PPP, PAN, partly PKS).

Aliran still structure the party system in general. They are different now from those in the 1950s, however. And instead of distinguishing between Geertzian abangan and santri, it is much more useful to differentiate between secularists and followers of political Islam. The most important cleavage structuring the party system as a whole since 1998 is the one dividing secular and Islamic parties. The latter, in turn, are divided into moderate and Islamist parties.

In order to adequately understand Indonesian party politics since 1998, different approaches have to be combined. Central mechanisms are still explainable with reference to notions of 'aliran'. Nevertheless, the political dynamics since Suharto imply a process of dealiranisasi and 'Philippinisation'. 
Philippine parties are characterised by weak platforms, a high frequency of party-switching, short-term coalition-building, factionalism, inactivity of the apparatuses in between elections, low membership figures, the dominance of presidential candidates, and rent-seeking politicians co-operating in cartels. A range of factors indicate a process that brings these two party systems closer to each other: firstly, the rise of presidential or presidentialised parties, a prime example being the Partai Demokrat of Susilo Bambang Yudhoyono; secondly, the authoritarianism and personalism with powerful 'party advisors' and executives which punish unruly members, marginalise intra-party opposition and further factionalisation; thirdly, the dominance of 'money politics' with bought candidacies, MPs acting as brokers for private companies, businessmen taking over party chairmanships, and billionaire financiers determining policies behind the scenes; fourthly, the erosion of ideologies with poor political platforms and decreasing party loyalties; fifthly, the cartel-like co-operation of parties as indicated by rainbow coalitions, an unorganised opposition, the musyawarah dan mufakat mechanism and the collusion in tolerating corruption; and lastly, the emergence of new, powerful local elites. Some of these characteristics are more salient below the national level.

To be sure, 'Philippinisation' does not denote the full convergence of party politics in the two Southeast Asian countries. Local elites are more fractured in Indonesia and do not control parties in Jakarta. Party-switching is - at least at the national level - uncommon. Parties are far less presidentialised and political Islam still has a strong impact on parties' behaviour, whereas politicised religion in the Philippines does not structure the party system. The resilience of politik aliran hampers a full 'Philippinisation'.

But what accounts for the increasing similarity? In addition to national reconfigurations and legacies (the destruction of the radical political left, the vestiges of authoritarianism, etc.), global developments explain some of the trends in Indonesia. Because of the internationalisation and presidentialisation of politics, executives gain in importance. Moreover, the stability of traditional political loyalties is declining in general, and political leaders can appeal directly to voters via the mass media.

Another decisive factor is the specific economic transformation of Indonesia. Whereas in the 1950s political rent-seeking seems to have been contained to a certain degree by political competitors and active party supporters, by strong ideological commitments on the part of political leaders and in many cases by the sheer lack of opportunities, nowadays a cartelised elite sees politics to a great extent as business. The new symbiosis of entrepreneurs, politicians and state officials seems to be a direct result of the New Order and its coalition of rentseeking military, administrative and political elites. 
The development of the party system as described above is cause for concern. Indonesian parties may evolve further into Philippine-like political machines. It is also possible, though, that new ideologies will appear, either taking the form of a leftist neo-populism as in Latin America or - which is more likely - as Islamisation. Because of the decline of abangan orientations and the impact of Western secular ideas, new religious divides are being constructed. Religion is repeatedly politicised for this reason. In parliament, religious issues set heated discussions in motion, the latest examples being the debates on the anti-pornography bill and on the introduction of sharia laws at the regional level. To be sure, this does not outweigh the illustrated erosion of traditional loyalties and party structures. 


\section{References}

Ananta, A./Arifin, E.N./Suryadinata, L. (2004): Indonesian Electoral Behaviour. A Statistical Perspective; Singapore.

Ananta, A./Arifin, E. N./Suryadinata, L. (2005): Emerging Democracy in Indonesia; Singapore.

Anderson, B. (1996): Elections and Participation in Three Southeast Asian Countries; in: Taylor, R.H. (ed.): The Politics of Elections in Southeast Asia; Cambridge; pp. 12-33.

Antlöv, H. (2004a): Introduction; in: Antlöv, H./Cederroth, S. (eds.): Elections in Indonesia: The New Order and Beyond, London and New York; pp. 1-17.

Antlöv, H. (2004b): National elections, local issues: the 1997 and 1999 national elections in a village on Java; in: Antlöv, H./Cederroth, S. (eds.): Elections in Indonesia: The New Order and Beyond; London and New York; pp. 111-137.

Arlegue, C./Coronel, J.J.S. (2003): Philippines; in: Manikas, P.M./Thornton, L.L. (eds.): Political Parties in Asia: promoting reform and combating corruption in eight countries; Washington D.C.; pp. 217-262.

Asia Foundation (2003): Democracy in Indonesia. A Survey of the Indonesian Electorate 2003; Jakarta.

Aspinall, E. (2005): Elections and the normalization of politics in Indonesia; in: South East Asia Research; 13, 2; pp. 117-156.

Bertrand, R. (2004): 'Behave Like Enraged Lions': Civil Militias, the Army and the Criminalisation of Politics in Indonesia; in: Global Crime; Vol. 6, No. 3\&4; pp. 325-344.

Cederroth, S. (2004): Traditional power and party politics in North Lombok, 1965-99; in: Antlöv, H. / Cederroth, S. (eds.): Elections in Indonesia: The New Order and Beyond; London and New York; pp. 77-110.

Choi, N. (2004): Local Elections and Party Politics in Post-Reformasi Indonesia: A View from Yogyakarta, Contemporary Southeast Asia, August, pp. 280-301.

Djadijono, M. (2006): Ideologi Partai Politik (Ideology of Political Parties); in: Piliang, I.J./ Legowo, T.A. (eds.): Disain Baru Sistem Politik Indonesia; Jakarta; pp. 71-88.

Fealy, G. (2001): Parties and Parliament: Serving whose Interests?; in: Lloyd, G. / Smith, S. (eds.): Indonesia Today: Challenges of History; Singapore; pp. 97-111.

Feith, H. (1957): The Indonesian Elections of 1955; Ithaca.

Feith, H. (1962): The Decline of Constitutional Democracy in Indonesia; Ithaca.

Geertz, C. (1960): The Religion of Java; London.

Geertz, C. (1963): Peddlers and Princes; Chicago. 
Geertz, C. (1965): The Social History of an Indonesian Town; Cambridge, Massachusetts.

Gerakan Pembaruan PDI Perjuangan (2005): Demokrasi Seolah-Olah. Tinjauan Kritis Kongres Ke-2 PDI Perjuangan (Pseudo-Democracy. A Critical Observation of the Second PDI-Perjuangan Congress); Jakarta.

Hadiwinata, B.S. (2006): The 2004 Parliamentary and Presidential Elections in Indonesia; in: Croissant, A./Martin, B. (eds.): Between Consolidation and Crisis. Elections and Democracy in Five Nations in Southeast Asia; Berlin; pp. 85-146.

Hadiz, V. (2004a): Indonesian Local Party Politics. A Site of Resistance to Neoliberal Reform; in: Critical Asian Studies; 36:4; pp. 615-636.

Hadiz, V. (2004b): Decentralization and Democracy in Indonesia: A Critique of NeoInstitutionalist Perspectives; in: Development and Change; 35 (4); pp. 697-718.

Haris, S. (2005): Proses Pencalonan Legislatif Lokal. Pola, Kecenderungan, dan Profil Caleg (The Process of Nominating Local Candidates. Patterns, Tendencies, and the Profile of Legislative Candidates); in: Haris, S. (ed.): Pemilu Langsung di Tengah Oligarki Partai. Proses nominasi dan seleksi calon legislatif Pemilu 2004 (Direct Elections among Party Oligarchies. Nomination Process and Selection of Legislative Candidates in the 2004 Elections"); Jakarta; pp. 1-27.

IFES (International Foundation for Electoral Support) (2004a): Results from Wave XV of Tracking Surveys, August 2004; Jakarta.

IFES (International Foundation for Election Systems) (2004b): Results from Wave XVIII of Tracking Surveys, 19 October 2004; Jakarta.

Johnson Tan, P. (2002): Anti-Party Reaction in Indonesia: Causes and Implications; in: Contemporary Southeast Asia; Vol. 24, No. 3; pp. 484-508.

Johnson Tan, P. (2004): Party Rooting, Political Operators, and Instability in Indonesia: A Consideration of Party System Institutionalization in a Communally Charged Society; http://people.uncw.edu/tanp/SPSA2004.html, accessed on 13.3.2005.

Johnson Tan, P. (2006): Indonesia Seven Years after Soeharto: Party System Institutionalization in a New Democracy; in: Contemporary Southeast Asia; Vol. 28, No. 1; pp. 88-114.

Katz, R.S./Mair, P. (1995): Changing Models of Party Organization and Party Democracy. The emergence of the Cartel Party; in: Party Politics; 1(1); pp. 5-28.

King, D.Y. (2003): Half-Hearted Reform. Electoral Institutions and the Struggle for Democracy in Indonesia; Westport, Connecticut and London.

Kirchheimer, O. (1966): The Catch-all Party; in: Mair, P. (ed. 1990): The West European Party System; Oxford; pp. 50-60. 
Kompas (2004a): Peta Politik Pemilihan Umum 1999-2004 (Political Map of the General Elections 1999-2004); Jakarta.

Kompas (2004b): Partai-Partai Politik Indonesia. Ideologi dan Program 2004-2009 (Indonesian Political Parties. Ideology and Programme 2004-2009); Jakarta.

Lembaga Survei Indonesia (2006): Two Years of Party Performance: A Public Evaluation; Jakarta.

Liddle, R.W.(2003): New Patterns of Islamic Politics in Democratic Indonesia; in: Asia Program; no.110; Woodrow Wilson International Center for Scholars; Washington, D.C.; pp. 4-13.

Lipset, S. /Rokkan, S. (1967): Cleavage structures, party systems, and voter alignments: An introduction; in: Lipset, S./Rokkan, S. (ed.): Party Systems and Voter Alignments: CrossNational Perspectives; New York; pp. 1-64.

Mainwaring, S. (1993): Presidentialism, Multipartism, and Democracy. The Difficult Combination; in: Comparative Political Studies; Vol. 26 No.2; July; pp. 198-228.

Mietzner, M. (2005): Local Democracy; in: Inside Indonesia; No. 85; pp. 17-18.

Mietzner, M. (2007): New Rules for Old Elites: The 2005 Gubernatorial Elections in North Sulawesi and Indonesia's Long Road to Democracy; in: Bünte, M. / Ufen, A. (eds.): Democratization in Post-Suharto Indonesia: The Transformation of a Hybrid Regime; forthcoming.

Mortimer, R. (1969): The Downfall of Indonesian Communism; in: Miliband, R./Saville, J. (eds.): The Socialist Register; London; pp. 189-217.

Mujani, S./Liddle, W. (2006): Leadership, Party and Religion: Explaining Voting Behavior in Indonesia; in: Comparative Political Studies; forthcoming.

Nohlen, D. (2004): Wahlrecht und Parteiensystem; Opladen.

Notosusanto, S. (2005): Analisa AD/ART Partai Politik (Analysis of Political Parties' Statutes); www.forum-politisi.org/arsip/article.php?id=113, accessed on 16.9.2006.

Poguntke, T. / Webb, P. (2005) (eds.): The Presidentialization of Politics. A Comparative Study of Modern Democracies; Oxford.

Rifai, A. (2003): Politik Uang Dalam Pemilihan Kepala Daerah (Money Politics in the Election of Regional Heads); Jakarta.

Rinakit, S. (2005): Indonesian Regional Elections in Praxis; IDSS Commentaries; Singapore.

Robison, R./Hadiz, V.R. (2004): Reorganizing Power in Indonesia: The Politics of Oligarchy in an Age of Markets; London and New York. 
Rocamora, J.E. (1975): Nationalism in Search of Ideology: The Indonesian Nationalist Party, 1946-1965; Quezon City.

Rocamora, J. (2000): Formal Democracy and its Alternatives in the Philippines: Parties, Elections and Social Movements; www.tni.org/archives/rocamora/formal.htm, accessed on 12.7.2006.

Rüland, J. (2001): Indonesia; in: Nohlen, D./Grotz, F./Hartman, C. (eds.): Elections in Asia and the Pacific: A Data Handbook, Vol. II; Oxford; pp. 83-128.

Samuels, D.J. (2002): Presidentialized Parties. The Separation of Powers and Party Organization and Behavior; in: Comparative Political Studies; Vol.35; No.4; May; pp. 461-483.

Sebastian, L.C. (2004): The Paradox of Indonesian Democracy; in: Contemporary Southeast Asia; August, pp. 256-279.

Sherlock, S. (2004): The 2004 Indonesian Elections: How the System Works and What the Parties Stand For (A Report on Political Parties); in: Kajian, March; Jakarta; pp. 1-43.

Sherlock, S. (2005): The Role of Political Parties in a Second Wave of Reformasi; UNSFIR, Jakarta.

Sidel, J. (1999): Capital, Coercion and Crime: Bossism in the Philippines; Stanford.

Slater, D. (2004): Indonesia's Accountability Trap: Party Cartels and Presidential Power after Democratic Transition; in: Indonesia; No.78; pp. 61-92.

Sundhaussen, U. (1989): Indonesia: Past and Present Encounters with Democracy; in: Diamond, L./Linz, J.J./Lipset, S.M. (eds.): Democracy in Developing Countries. Democracy in Asia. Boulder, Colorado; pp. 423-474.

Suryakusuma, J. (1999) (ed.): Almanak Parpol Indonesia (Almanac of Indonesian Political Parties"); Jakarta.

Teehankee, J. (2006): Consolidation or Crisis of Clientelistic Democracy? The 2004 Synchronized Elections in the Philippines; in: Croissant, A./Martin, B. (eds.): Between Consolidation and Crisis. Elections and Democracy in Five Nations in Southeast Asia; Berlin; pp. 215-276.

Tomsa, D. (2006a): The Defeat of Centralized Paternalism: Factionalism, Assertive Regional Cadres, and the Long Fall of Golkar Chairman Akbar Tandjung; in: Indonesia; Vol. 81; April; pp. 1-22.

Tomsa, D. (2006b): Dominance by Default: Golkar and Uneven Party Institutionalization in Post-Suharto Indonesia; PhD Diss.; Asia Institute, The University of Melbourne; Melbourne. 
Turmudi, E. (2004): Patronage, aliran and Islamic ideologies during elections in Jombang, East Java, in: Antlöv, H./Cederroth, S. (eds.): Elections in Indonesia: The New Order and Beyond; London and New York; Routledge; pp. 38-60.

Vel, J. (2005): Pilkada in East Sumba: An Old Rivalry in a New Democratic Setting; in: Indonesia; Vol. 80, October; pp. 81-107.

Wertheim, W.F. (1969): From Aliran to Class Struggle in the Countryside of Java; in: Pacific Viewpoint; X:2; September; pp. 1-17.

Widodo, A. (2003): Changing the cultural landscape of local politics in post-authoritarian Indonesia: the view from Blora, Central Java; in: Aspinall, E. / Fealy, G. (eds.): Local Power and Politics in Indonesia: Decentralisation and Democratisation; Singapore; pp. 179-193. 


\section{G

\section{Recent issues:}

No 36 Juliane Brach: Ten Years after: Achievements and Challenges of the Euro-Mediterranean Economic and Financial Partnership; December 2006

No 35 Christian von Soest: Measuring the Capability to Raise Revenue. Process and Output Dimensions and Their Application to the Zambia Revenue Authority; December 2006

No 34 Sebastian Huhn, Anika Oettler and Peter Peetz: Construyendo Inseguridades. Aproximaciones a la violencia en Centroamérica desde el análisis del discurso [Constructed insecurities. Discourse analysis and the understanding of violence in Central America]; November 2006

No 33 Sebastian Huhn, Anika Oettler and Peter Peetz: Exploding Crime? Topic Management in Central American Newspapers; November 2006

No 32 Christian von Soest: How Does Neopatrimonialism Affect the African State? The Case of Tax Collection in Zambia; November 2006

No 31 Susan Steiner: Decentralisation in Uganda: Exploring the Constraints for Poverty Reduction; November 2006

No 30 Detlef Nolte: Potencias regionales en la política internacional: conceptos y enfoques de análisis [Regional Powers in International Relations: Analytical Concepts and Research Approaches]; October 2006

No 29 Detlef Nolte: Macht und Machthierarchien in den internationalen Beziehungen: Ein Analysekonzept für die Forschung über regionale Führungsmächte [Power and Power Hierarchies in International Relations: Towards an Analytical Concept for the Study of Regional Powers]; October 2006

No 28 Bert Hoffmann and Laurence Whitehead: Cuban Exceptionalism Revisited; September 2006

No 27 Andreas Mehler: Political Discourse in Football Coverage - The Cases of Côte d'Ivoire and Ghana; August 2006

No 26 Martin Beck: Probleme des Rentierstaats-Ansatzes in vergleichender Perspektive [Problems of the Rentier State Approach in Comparative Perspective]; August 2006

No 25 Dirk Kohnert: Cultures of Innovation of the African Poor. Common Roots, Shared Traits, Joint Prospects? On the Articulation of Multiple Modernities in African Societies and Black Diasporas in Latin America; July 2006

No 24 Jan Peter Wogart: Multiple Interfaces of Big Pharma and the Change of Global Health Governance in the Face of HIV/AIDS; June 2006

No 23 Daniel Flemes: Brazil's Nuclear Policy. From Technological Dependence to Civil Nuclear Power; June 2006

All GIGA Working Papers are available free of charge at www.giga-hamburg.de/workingpapers. For any requests please contact: workingpapers@giga-hamburg.de.

Editor of the Working Paper Series: Bert Hoffmann. 